\title{
Informing Patterns of Student Case Writing
}

\section{John Ickis \\ INCAE Business School, Costa Rica}

john.ickis@incae.edu

\author{
Mislav Omazić \\ University of Zagreb, Zagreb, \\ Croatia
}

momazic@efzg.hr

During 2002-03, fifty-three undergraduate students from the University of Zagreb participated in the development of case studies on strategic decisions facing Croatian enterprises at a critical juncture in the country's history. This paper describes the informing patterns among students, faculty, and business executives that were formed during the case writing process and examines the impact of these informing patterns upon the educational experience of the participants and their subsequent careers.

Keywords: Case Writing, Management Education, Croatia, Competitiveness, Pedagogy

Material published as part of this publication, either on-line or in print, is copyrighted by the Informing Science Institute. Permission to make digital or paper copy of part or all of these works for personal or classroom use is granted without fee provided that the copies are not made or distributed for profit or commercial advantage AND that copies 1) bear this notice in full and 2) give the full citation on the first page. It is permissible to abstract these works so long as credit is given. To copy in all other cases or to republish or to post on a server or to redistribute to lists requires specific permission and payment of a fee. Contact Publisher@InformingScience.org to request redistribution permission. 